Bryn Mawr College

Scholarship, Research, and Creative Work at Bryn Mawr

College

Political Science Faculty Research and Scholarship

Political Science

1994

\title{
Comparative Political Philosophy and Liberal Education: "Looking for Friends in History"
}

Stephen G. Salkever

Bryn Mawr College, ssalkeve@brynmawr.edu

Michael Nylan

Let us know how access to this document benefits you.

Follow this and additional works at: http://repository.brynmawr.edu/polisci_pubs

Part of the Education Commons, and the Political Science Commons

\section{Custom Citation}

Salkever, Stephen G., and Michael Nylan. "Comparative Political-Philosophy and Liberal Education: 'Looking for Friends in History."' PS: Political Science \& Politics 27, no. 2 (1994): 238-247.

This paper is posted at Scholarship, Research, and Creative Work at Bryn Mawr College. http://repository.brynmawr.edu/polisci_pubs/19

For more information, please contact repository@brynmawr.edu. 


\title{
The Teacher
}

\section{Comparative Political Philosophy and Liberal Education: "Looking for Friends in History"}

\author{
Stephen G. Salkever, Bryn Mawr College \\ Michael Nylan, Bryn Mawr College
}

Over the past eight years, we have jointly taught a series of courses comparing Chinese and European political philosophy. These courses have convinced us that teaching comparative political philosophy is a way of doing two eminently desirable-but seemingly incompatible-things at once: broadening the college curriculum by teaching texts from outside the Western tradition, and carrying out the historical job of liberal education by teaching students to become critical and articulate readers of interpretable texts. In our experience, there is no necessary incompatibility between liberal education and internationalizing the curriculum. To the contrary, we believe that at present neither of them will flourish without the other. We think that friends of the "great books" and friends of "multiculturalism" can and should share an extensive common ground, a ground we try to clarify here by making some proposals about the character of liberal education and by discussing ways in which teaching comparative political philosophy has helped us put these proposals into practice.

\section{Defining the Problem}

The kind of teaching that we (like most teachers of political theory) are comfortable with introduces students to books that present a variety of implicit and explicit claims about how lives should be lived and communities organized. These books are chosen on the basis of several not always harmonious criteria: their historical importance (since part of liberal education is coming to terms with a particular historical past or tradition); the extent to which they are open to conflicting interpretations (since critical interpretation and argument about the meaning of words and things is the practice that defines the liberal classroom); and the extent to which they can be read with an eye to questions and problems of the present (since liberal education is justified largely by its capacity to encourage deliberation and informed action in the future).

In deciding what books to teach, we worry less about adhering to conventional genre distinctions than about finding books that demand active and critical response, ones that incline us to reconsider the past and to imagine ourselves as participants in a continuing "conversation" about the shape of life in the future. Our goal in the classroom is not to transmit facts or values in any simple way; we aim to foster the preferences, skills, and habits of mind that support lives of persistent curiosity and self-reflection.

Liberal education understood in this way involves a balance of different and sometimes conflicting goods, so it is perhaps not surprising that the very notion of liberal education has been the subject of heated debate in America for most of this century. Nor should it surprise us that the most rhetorically successful formulations about liberal education are those that implicitly deny its complexity by reducing it to one of its constituent elements. ${ }^{2}$ The current "canon wars" illustrate this drift to oversimplification. It is difficult not to feel both sympathy and impatience with traditionalist arguments that the core of American liberal education should be a reverent celebration of the classics of the Western tradition, which are taken to provide permanent standards for judgments of truth and beauty. It is no less difficult not to feel conflicting emotions when presented with the usual radical arguments that such reverence papers over conflicts and injustices.

Traditionalists are right in claiming that an education refusing to engage Plato and Shakespeare as important teachers is short-sighted and thin. But radicals are right to insist that lists of books to be taught are not necessary phenomena imposing themselves on us like fate or a god, but constructed courses of study, establishing or preserving a particular version of the connection between the past and the present. The radicals are also right to insist that in developing college curricula we attend to changes in the character of the American undergraduate population and the society as a whole, recognizing that the classroom is no longer the exclusive preserve of white males, and that by the end of the decade European-Americans will no longer comprise a majority of the American population.

Traditionalists are wrong not to see these changes in the direction of a more diverse society as opportunities rather than threats, not to consider that "one of the most liberating effects of liberal education 
is in coming to see one's own culture as one possible form of life and sensibility among others." 3 But the radicals are wrong to think that the only appropriate stance toward books traditionally included in the canon is that of the avenging unmasker; worse, they may be blind to the way the analytic and evaluative categories that drive their radicalism rest on an unreflective privileging of one voice within that traditional canon, often a Marxist or a Nietzschean voice, rather than on genuine alternatives to the canon as such.

What is particularly exasperating about the canon wars debate is that both sides, in their eagerness to score points against each other, tend to ignore the most powerful ideological force in contemporary American undergraduate education-the practically hegemonic doctrine that such education must be organized on the lines of the academic disciplines as defined by the leading research universities. The dominance of this orthodoxy of disciplinary specialization seems to guarantee that the battles between traditionalists and radicals will be little more than noisy squabbles over limited stretches of curricular turf.

For the majority of the American professoriate, liberal education is nothing other than the name we give to a collection of different scholarly disciplines, and the heart of such education at the college level is rigorous training in a major. As disciplinary sub-specialties proliferate ${ }^{4}$ and technical vocabularies multiply, the likelihood becomes less and less that the college courses offered by the major disciplines will have much to contribute to the project of liberal education as we understand it. ${ }^{5}$ The canon wars adversaries, the radicals and the traditionalists, each oversimplify a complex task, but both know that liberal education cannot be taken to equal the sum of established research disciplines. Our problem, then, as teachers of political philosophy, lies in finding ways to embrace the partial goods championed separately by traditionalism and radicalism, while at the same time maintaining the kind of rigor that has come to be associated almost exclusively with scholarly work in the disciplines.

\section{But Is It Really "Philosophy"?}

When we began to plan our first course in Chinese and Greek political philosophy, we welcomed the chance to learn to read and discuss new and interesting books, with students and with each other. One of us is a specialist in Greek political philosophy who knew practically nothing about China; the other a specialist in the Chinese classics who knew little about Greece. We have since then jointly

\section{Our problem, then, as} teachers of political philosophy, lies in finding ways to embrace the partial goods championed separately by traditionalism and radicalism, while at the same time maintaining the kind of rigor that

has come to be

associated almost exclusively with scholarly work in the disciplines.

taught three courses combining Chinese and European texts. Each course begins from a particular problem that seems to be shared by Chinese and European thinkers, and the principal activity in all of them is a close reading of a relatively small number of works. 6

For example, our first course, on the origins of philosophy in China and Greece, began with what has been called the Socratic question, "What sort of life should I lead," the question that Plato's Socrates compels his interlocutors to con- front in the Republic and the Gorgias. Plausibly seen as the event that initiates moral and political philosophy in the West, we suggest that Socrates' question can with equal justice be called Confucius's question, insofar as Confucius like Socrates insists that his pupils ask novel and profound questions about their society and its practices-all the while denying that he has anything new to teach. ${ }^{7}$

To make a long story short, we treat Confucius and Socrates not as authors of doctrines to compare, nor as representative thinkers of their respective "cultures," 8 but as figures who use analogous modes of unsettling, critical self-inquiry. Socrates does this by insisting on a fresh examination of familiar concepts like excellence (arete) and good (agathon), and placing familiar patterns of social life, such as laws (nomoi) and crafts (technai), in a new light in a way that leads to further reflection; Confucius problematizes the traditional meanings assigned to familiar terms like humanity (jen), ceremony (li), and the gentleman (chün tzu), and does so in such a way that the reader is led to connect particular terms and practices with some elusive yet somehow intelligible whole. ${ }^{9}$ Read in this way, the Confucius and Socrates our courses presuppose are neither timeless thinkers abstracted from historical context nor typical or official Chinese or Greek voices; we are, to borrow a phrase from the fourth-century B.C. Confucian philosopher, Mencius, "looking for friends in history." 10

To this point we have been speaking of Chinese philosophy without remarking on the phrase. But the idea that philosophy exists only or primarily in the West-it is, after all, a Greek word-has been widespread, especially among those identified with the contemporary academic discipline that goes by that name. The orthodox view is stated by John Passmore, in his article, "Philosophy," in the latest Encyclopedia of Philosophy. Passmore sharply distinguishes true philosophy from poetry or sagehood (both of which he regards as the same woolly minded thing): discourse counts as philosophy if it is 
a "clear, articulate, discussible system of ideas and principles." Given that criterion for philosophy, Passmore says that, "What is commonly called 'Chinese philosophy' ... consists almost entirely of the pronouncements of sages" (Passmore, 1967, 216-18).

This notion of how to separate philosophy from other forms of expression is widespread, and is the way the term philosophy is used in academic departments of philosophy within the Anglo-American analytic tradition. ${ }^{11}$ But this is a conception of philosophy that is historically limited and tied to controversial substantive presuppositions about the character of inquiry and reality. The notion of philosophy as systematic and as free from ambiguity as possible ${ }^{12}$ dates from the seventeenth-century efforts of Descartes, Hobbes, and Spinoza to establish a basis of absolute certainty for scientific inquiry, modified by Kant's eighteenth-century shift of analytic focus from the foundations of world to the foundations of human understanding. Such a conception of philosophy excludes not only Chinese philosophy but pre-modern Europeans like Plato and Aristotle, who were anything but systematic and who rejected the idea that the system and precision of mathematics or symbolic logic provide appropriate models for philosophic reasoning and philosophic discourse. ${ }^{13}$

Every philosopher wishes to be as systematic and univocal as possible-the substantive disagreement between Passmore and the Cartesians on the one hand and the ancient Chinese and Greek thinkers on the other is over the extent to which it is necessary to call attention to and preserve verbal ambiguity, and to use modes of argument other than deductive entailment in order to give a picture of the world that clarifies rather than distorts the human situation.

There is another way of conceiving philosophy, one that fits our intentions better without including every kind of belief or expression. Philosophy brings to consciousness and articulateness those prevailing orientations toward and beliefs about individuals, society, and the cosmos that are otherwise tacit-in effect, philosophy begins with the Socratic/Confucian question about how we should live, and not with the Cartesian or Kantian impulse toward certainty and system. Philosophizing of the Socratic/Confucian kind indeed demands a certain kind of rationality by insisting that reasons be given for accepting as good or true what we might otherwise do or believe out of ancient custom or pious awe-but this is not rationality on the model of deductive proof, and it may well be one that calls for expression in poetry or aphorism or story rather than bare prose. ${ }^{14}$ This conception of rationality presupposes a world in which our fundamental questions have greater stability and permanence than any answers we may give them. The point of philosophizing in such a world is to bring those questions to consciousness, not to supply precise and absolute solutions.

Philosophy thus appears as an ever-present human possibility, rather than the systematized and mathematicized thought of a particular individual or group; the danger to be avoided here is the reduction of practical philosophic inquiry to scientistic "ethnophilosophy." 15 Comparative philosophy must resist the inclination to explain philosophic texts of a particular culture as superstructural representations of the "essence" of that culture (Nussbaum and Sen 1989, 302). We are all familiar with the better known examples of this infectious temptation.

In comparing Chinese and Greek texts, for example, we may be told that the key to their meaning lies in material conditions, ${ }^{16}$ or in the attributes of one culture that seem to be "missing" in the other; for example the asserted "absence" of a "scientific revolution" or of the verb "to be" (Graham), or of cosmogonic myths (Mote), or of individual military heroes (Keightley) in China. Such "missing" attributes are used by different authors to demonstrate either the inferiority or the superiority of Chinese to Europeans, ${ }^{17}$ but whatever their evaluative use, "missing attribute" analyses elevate a partial truth to the status of a core explanatory reality, and in the process make each text and culture so exotic to the other that any inter-textual or inter-cultural dialogue becomes impossible. ${ }^{18}$

\section{Course Planning Strategies}

In designing courses, we have avoided organizing the syllabuses as surveys; instead, we try to have each course focus on one permanent human problem confronted in two very different places: for instance, how to think one's way outside the limits of prescribed social roles; how to imagine and respond to death; or how to combine innovation and continuity in societies where traditional authority has been shaken. Of course, each philosophic text speaks to a number of interesting problems, so class discussion will inevitably (and rightly) drift into a number of areas unrelated to the initial problem used to organize the course.

The word we choose to name the context in which these problems arise-whether culture, or world of thought (following Benjamin Schwartz), or tradition-is not important, but the problem of how we understand that context matters a great deal and needs to be carefully considered by those of us interested in reading philosophic texts in a comparative way. We need to avoid going too far in the direction of reducing texts to context by treating them as a mere products of culture forces; such a reductive explanation makes it impossible to take the text seriously as a "friend" to argue with. But we also need to avoid the opposite error of treating the texts as absolutely context-free, as isolated miracles of timelessness whose authors were our immediate contemporaries, for this would be to discount the difficulties inherent in translating and understanding our "friends."

In other words, in comparative philosophy we need to bear in mind both the existence of boundaries and the possibility of boundary crossing. To appreciate the strangeness of a text while at the same time looking for ways to connect 
its language to ours, it may help to borrow Gadamer's notion of the "horizon," by which he means the questions to which each text can be seen as an answer. ${ }^{19}$ To establish a "horizon" for an intelligent first reading of Plato's Apology or the Confucian Analects, we need a sense of fifth-century Athens or $\mathrm{Lu}$ so that we can bring the appropriate questions to our texts. But the texts must then be seen as active and individual responses to those questions-not as what the typical Greek or Chinese philosopher would say. ${ }^{20}$

There is no single right way to organize comparative courses, but there are several considerations we think are important. First, in planning the course, do not set it up as two consecutive historical survey courses (e.g., half a term on Chinese classics followed by half a term on Greek classics). The object is to draw tentative comparisons between individual texts from different traditions as soon as possible. As you can see from the appended syllabuses, we've tried to do this in various ways. We have also discovered that almost any pairing of two texts can work, so that it is pointless to agonize over whether Plato is better paired with Confucius or Chuang Tzu. As the course proceeds, comparisons can be made freely both within and across cultures, so long as one always bears in mind that the point of these comparisons is not to come up with or test the truth of generalizations about cultural similarities and differences, ${ }^{21}$ but to become more sensitive and more active listeners to the individual voices in the books we read.

Second, it seems to work better to organize courses around problems that arise in the texts and in our lives, rather than chronologically or by concepts central to contemporary disciplinary concerns. It wouldn't make sense, for example, to have a course structured around the problem of how the ancient Chinese writers might come down on the issue of communitarianism versus Rawlsian liberalism. Nor should you aim at a thorough historical survey, although we have found that dealing with works from roughly the same historical period helps keep students from feeling hopelessly at sea. The particular content of the course should be determined by the people who are going to teach it, and will reflect their own interests and areas of expertise, as do our three syllabuses printed below.

\section{Writing frequent papers} gives our students the chance both to solidify their understanding of the readings and to try out different ways of constructing an active

\section{response to different kinds of texts.}

This is also true of the mix of books from different traditions-it isn't necessary to have half from one tradition and half from the other. Nevertheless, it is important to have some care about the proportions, lest students get the impression that one tradition is somehow more important and more valuable because it is the source of more of the readings. In our "Origins of Philosophy" class, the texts are approximately half Chinese and half Greek. In "Piety and Death" and "Brave New Worlds," the ratio is $2 / 3$ European to $1 / 3$ Chinese-since here there were three teachers, two of us European specialists. This may be as unbalanced as we would want to go.

Above all, we caution against including only one non-Western text in a course that is otherwise strictly Western. It is absolutely necessary to indicate that neither the Chinese nor the Western tradition is monolithic, and that they are interesting to us precisely because they contain rich debates over substantial practical and theoretical issues. To include one non-Western book as if it somehow "represented" the Chinese, or, worse, the "third world perspective," distorts more than it illuminates.

The best way to avoid the urge to turn books into emissaries from exotic cultures is to familiarize yourself as soon as possible with the contending alternatives within the tradition that is new to you as a teacher. For those first encountering Chinese philosophy, Arthur Waley's Three Ways of Thought in Ancient China is a fine place to begin, as are Benjamin Schwartz's Search for Wealth and Power and World of Thought in Ancient China, and A.C. Graham's Disputers of the Tao, since all these books alert the reader to the complexity of the tradition as they dispel stereotypic conceptions of the Chinese Geist. ${ }^{22}$

Once you have settled on texts, the next question is how to balance lecture and discussion-in other words, how to balance the need for establishing a contextual background against the need to allow students to develop their own readings of the texts. Both are necessary, and finding the right mix will depend on local factors. We have done it in two ways: in the "Origins" course (an upper-level seminar), whoever is the specialist for the day's reading leads the discussion, supplying background as necessary. In lower-level courses, one lecture a week given by the resident expert precedes two weekly meetings for discussion. It is a good idea to modify the "experts first" rule over time as the nonexpert faculty become more familiar with new material; this makes it clear that you don't have to be an expert to raise good questions about a text.

Finally, there is the matter of student assignments. Putting a lot of weight on quizzes and examinations, or on a long research or term paper, is a sure way to undermine the goals of the course. Students should write as many short papers as possible (between four and seven papers a term), ideally of varying length (from two to ten pages). If students are required to write a number of shorter papers, the stakes involved in writing each are lowered, and the chances for improving over the course of the 
term are increased. Writing frequent papers gives our students the chance both to solidify their understanding of the readings and to try out different ways of constructing an active response to different kinds of texts. We give students the option of rewriting their papers at any time, since this encourages the timid to take risks and allows all students to check their own progress.

Several types of paper topics seem to work well. In general, in a short paper it seems better to ask students to focus on interpreting one text while bringing others in as points of comparison, since it takes a great deal of sophistication to give two complex texts equal weight in a short paper without oversimplifying. Three sorts of topics that have proved successful are those that point to a moral or political dilemma that is seemingly left unresolved by the text (such as the conflict between familial and communal obligations posed by the story of Upright Kung in Analects 13.18); those that take off from an apparent tension between aspects of a single text; and those that ask students to respond to some controversial interpretation of the text (such as J. B. White's critique of Thucydides' Diodotus, or David Wong's claim that Hsün Tzu is a "prototechnological" thinker). In all of these, our aim is to have students move from very particular moments in the text to broader questions. One way to do this is to ask students to consider themselves modern disciples of the ancient masters.

Our responses to these papers are perhaps even more important than our choice of paper topics. We try to arrange that both of us comment on the same paper, at least some of the time, to let students see that a variety of approaches is possible. In larger classes, of course, and for those with heavier teaching loads than our $3 / 2$, this will not be possible. But here one could still try experimenting with short, ungraded, written assignments (perhaps 15-20 minute in-class writings) that are then discussed in small groups. At any rate, thinking about the kind of writing students do in these courses should not be treated as separate from thinking about the substance of the course. It is not a matter of evaluation and grading only: our expectations about and responses to student writing directly affect the development of those interpretive skills and habits needed to address the Socratic/Confucian question.

\section{Notes}

1. A longer version of this paper, entitled "Teaching Comparative Political Philosophy: Rationale, Problems, Strategies, or, On Trying To Avoid The Anthropologist/ Economist/Missionary Trilemma," was presented at the 1991 Annual Meeting of the American Political Science Association, and is available from the authors on request. The subtitle refers to our attempt to teach philosophical texts comparatively while avoiding three things: the contextualist reduction of philosophy to an aspect of the anthropologist's "culture"; the universalist reduction of philosophy to an effect of the economist's laws; and the moralistic reduction of philosophy to good and bad dogmas by sectarian missionaries both religious and secular.

2. As Tocqueville noted, busy democrats tend to be addicted, against their own best interests, to simplifying theories.

3. Searle, p. 39. Kermode's discussion of the uses of "classic" texts is most helpful, especially for his account of the conflict about how the classic should be represented, between those who see "the classic as a closed book that learning can partly open, and those who assert that the classic is a more or less open text from which new readings may be generated, not the charms of antiquity imperfectly understood, but important new senses"' (p. 75). Two other strong nontraditional defenses of the centrality of classical texts for liberal learning are Wayne Booth, The Company We Keep, and Eva Brann, Paradoxes of Education in a Republic.

4. And such proliferation is the way scholarly disciplines typically resolve internal disputes, no matter how fundamental. Both traditionalists and radicals are comfortably accommodated within the framework of existing disciplines and the departmental structure of research universities. Gerald Graff's study of the history of American departments of English over the last hundred years documents and discusses this tendency and its negative implications for liberal education. Graff's central point is that radical challenges are typically resolved by establishing new faculty positions for the erstwhile radicals, rather than by a debate about how the department should understand its purpose followed by a re-organization of the faculty in the light of that debate.

5. This dilemma is both recognized and exemplified in the recent APSA report on "Liberal Learning and the Political Science
Major" (Wahlke 1991). Recognizing that the major should not be "a pre-professional program to train political scientists" (p. 50), but reluctant to criticize or exclude any currently prominent research program, the report in effect throws up its hands at settling on a set of questions or approaches to guide undergraduate education and says that students should learn to ask, "Which particular mode of analysis is appropriate to this particular question" (p. 52)-as if "modes of analysis" had no part in setting both the terms and the substance of the questions they address. Kaufman-Osborne (1990) makes a cogent historical argument for freeing our thoughts about the undergraduate major from the "imperialism" of the research practices prevailing in graduate departments.

6. So far we have offered an upper-level course on the origins of philosophy in China and Greece several times, a sophomore-level course on texts from the European and Chinese enlightenments, called "Brave New Worlds," and a seminar for freshmen and sophomores on ways of thinking about piety and death in ancient China and Greece. We could not have begun to teach any of these courses without outside support to cover our other course commitments. The development of the first course was supported by a grant from the Ford Foundation; the other two were funded by a Knight Foundation grant.

7. This fundamental parallel between Socratic and Confucian activity is brilliantly drawn by Benjamin Schwartz (1985), 76-79. Schwartz is pre-eminent among specialists in early Chinese philosophy in his understanding of Greek philosophy, and hence in his ability to draw thought-provoking comparisons between the two traditions. Any specialist in European political theory who wants to begin reading the Chinese classics would do well to read The World of Thought in Ancient China at the first opportunity.

8. The structuralist trope of constructing an invisible agent and calling it the "culture" of a people destroys philosophy, and especially comparative philosophy, and is to be avoided. The reification of culture belongs to anthropology, and is especially visible in traditional ethnographic functionalism, which seems to operate on the maxim that, as Aristotle didn't say, Culture makes nothing in vain. The word "society" has been used similarly by sociologists like Durkheim, for whom, Alan Wolfe says, "Society is like the hero of an epic saga, possessing superhuman qualities at which ordinary mortals can only wonder"' (p. 221).

9. In the case of old words used in new ways, Eno's discussion of the Confucian texts suggests that it might be fascinating to compare the way Plato and Aristotle use phusis (roughly, nature) with the transformations of $t$ 'ien (roughly, heaven) in Confucius, Mencius, and Hsün Tzu. For a very interesting discussion of the similar work done by dunamis/energeia (potentiality/actuality) in Aristotle and ch'illi (energy/principle) in Chu Hsi, see Clark, pp. 212-16.

10. Mencius 5b8, p. 158 in the D. C. Lau translation. Wayne Booth, with no reference to Mencius, but with Aristotle's discussion 
of friendship in mind, presents a similar way of thinking about books. For Booth, the value of reading is the creation of an ethical culture in which we make friends with the author of the text-not the historical author, but the one implied or constructed by our reading. "Friendship" here suggests various kinds of friends-those who are simply fun to be with because they flatter or amuse us, those who are useful informants about something that we need to know about, but especially those who can criticize as well as confirm our deepest commitments and habits.

11. One of the curious hallmarks of this group is its tendency to claim that what it does isn't "analytic" philosophy at all, it's just plain philosophy, philosophy tout court - after all, who could be against clarity and articulateness? T. Irwin exhibits the characteristic tone and substance of this refusal to grant even the possibility that the term philosophy might be contested: "I rather deprecate the use of the term AngloAmerican [his italics] to refer to a philosophical school or outlook. And I doubt if there are any techniques characteristic of contemporary Anglo-American (as opposed to medieval Latin or eighteenth-century German) philosophy" (in Griswold, p. 195).

12. A view of the character of philosophy roughly similar to that of post-Cartesian European philosophers-valuing strict deductive argument and aspiring to univocity at all times-seems to have been held in ancient China by the Mohist "logicians," whose writings were marginalized as impractical by later canon builders.

13. See the articles in Griswold for a sense of the debate about Plato-interpretation between analytic philosophers and others.

14. Schwartz (1985) discusses the emergence of philosophy understood in this way in terms of Karl Jaspers' concept of the "Axial Age," the period during the first millennium B.C., when a new kind of writing and thought began to appear in several places, including China and Greece, writing in which one finds something different from a priestly enunciation of prevailing codes and beliefs, but instead, in Schwartz's words, "a kind of standing back and looking beyond; of questioning and reflectivity as well as the emergence of new positive perspectives and visions" (p. 3). Robert Eno makes an excellent case for reading the Analects as a "philosophically self-conscious text"' (p. 81) in these terms. Eno also provides good readings of Mencius and $H$ sün Tzu as texts of this kind. For related arguments about the philosophic character of the Chuang $T z u$, see Wu, especially pp. 266-77, and Hansen (1983); for Mencius, see Yearley (1990). All stress the different ways in which these authors insist on giving reasons rather than accepting rules or revelations, and the need to take seriously their claims to true belief and persuasive argument if we are to be adequate readers. For a comparable treatment of the meaning of Socratic logos as something different from either deductive logic or prophetic vision, see Desjardins (1990).

15. For insightful discussions of this issue and of the question of African philosophy in comparative perspective generally, see Appiah (1992) and Outlaw (1993).

16. For Jacques Gernet (pp. 26-29), the primary explainer of cultural difference is that the Greeks were seafarers and pastoralists, while the Chinese were settled agriculturists.

17. The "absence" of cosmogony "causes" the Chinese to have a uniquely organismic view of the universe, one that makes no distinction between facts and values (Graham, p. 29), and one that never separates subjectivity from the world (Tu, p. 12), one that sees value as immanent in the world rather than a matter of external universal principle (Hall and Ames, pp. 32325) - in all these cases, the "absence" is presented as the reason the Chinese have been able to avoid some bad beliefs; or, they can be used to show that the Chinese never had a "scientific revolution" (Sivin's critique of this way of stating the question is very helpful) or a sense of individual

"rights"- these things being (usually) taken to be good. The process here often seems to be that an author adopts a prevailing (Western) critique of Western philosophy, generally one stemming from the Nietzschean and/or Heideggerian critique of fundamental ontology, and then proceeds to find that critique already present (though never, of course, explicit-that's what our author is for) in Chinese philosophy. Pocock (pp. 1718), speaking of the Westernizing distortions in the readings of certain Chinese texts that are inspired by the desire to discover a Good Other that appears to manifest the opposite of everything we hate about ourselves, waxes appropriately satiric: "It is very easy to understand the appeal of this perception for moderns trying to live in a post-individualist, post-industrial and probably post-revolutionary world . . . though when it [the idea of the Taoist self and the politics of the wu wei] is practised in faece Calvini, among the debris of Protestant individualism, some very curious jetsam enters the original current." (pp. 17-18).

18. See Girardot for an argument that the question of Chinese cosmogony is much, more complex than the simple "absence" analysis suggests; see Graham (pp. 389-428) for similarly complicating the issue of expressions in Chinese (and other languages) comparable to the English "to be" or the Greek einai, and an interesting and appropriately inconclusive discussion of the advantages and disadvantages of the different formulations.

19. Gadamer, pp. 333-40. Gadamer takes this idea-that the way to determine the meaning of a text is to try to reconstruct the question to which the text is an answerfrom the Autobiography of R. G. Collingwood.

20. "Thus a person who seeks to understand must question what lies behind what is said. He must understand it as an answer to a question. . . . We understand the sense of the text only by acquiring the horizon of the question that, as such, necessarily includes other possible answers" Gadamer, p. 333.

21. Of course, hypotheses of this kind can and should be floated all the time-but they cannot become the goal of the course with- out subverting its purposes, at least as we understand them. Schwartz $(1964$, p. 2$)$ notes that in discussing cross-cultural encounters we need to take care to avoid treating cultures as static monoliths: "I would suggest that in dealing with the encounter between the West and any given non-Western society and culture, there can be no escape from the necessity of immersing ourselves as deeply as possible in the specificities of both worlds simultaneously. We are not dealing with a known and an unknown variable but with two vast, everchanging, highly problematic areas of human experience."

22. For the social and political history of pre-Ch'in China, Hsu Cho-yun, Ancient China in Transition is a good introduction; for the political context of Athenian philosophy, see J. Ober, Mass and Elite in Athenian Democracy.

\section{References}

Appiah, Kwame Anthony. 1992. In My Father's House: Africa in the Philosophy of Culture. Oxford: Oxford University Press.

Booth, Wayne C. 1988. The Company We Keep: an Ethics of Fiction. Berkeley and Los Angeles: University of California Press.

Brann, Eva. 1979. Paradoxes of Education in a Republic. Chicago: University of Chicago Press.

Chuang Tzu: Basic Writings. 1964. Trans. Burton Watson. New York: Columbia University Press.

Clark, Stephen R. L. 1975. Aristotle's Man: Speculations upon Aristotelian Anthropology. Oxford: Clarendon Press.

Confucius. Analects. 1938. Translated and annotated by Arthur Waley. New York: Random House.

Desjardins, Rosemary. 1990. The Rational Enterprise: Logos in Plato's Theaetetus. Albany, NY: SUNY Press.

Eno, Robert. 1990. The Confucian Concept of Heaven: Philosophy and the Defense of Ritual Mastery. Albany, NY: SUNY Press.

Gadamer, Hans-Georg. 1975. Truth and Method. Trans. G. Barden and J. Cumming. New York: Continuum.

Gernet, Jacques. 1982. A History of Chinese Civilization. Trans. J. R. Foster. Cambridge: Cambridge University Press.

Girardot, Norman J. 1985. "Behaving Cosmogonically in Early Taoism." In Cosmogony and Ethical Order, Robin W. Lovin and Frank E. Reynolds, eds., 6797. Chicago: University of Chicago Press.

Graff, Gerald. 1987. Professing Literature: An Institutional History. Chicago: University of Chicago Press.

Graham, A. C. 1989. Disputers of the Tao: Philosophical Argument in Ancient China. La Salle, IL: Open Court Publishers.

Griswold, Charles L., Jr., ed. 1988. Platonic Writings/Platonic Readings. New York and London: Routledge. 
Hansen, Chad. 1983. "A Tao of Tao in Chuang-tzu." In Experimental Essays on Chuang-tzu, ed. Victor H. Mair. Honolulu: University of Hawaii Press.

Hsu Cho-yun. 1965. Ancient China in Transition: An Analysis of Social Mobility, 722-222 B.C. Stanford: Stanford University Press.

Hsün Tzu: Basic Writings. 1963. Trans. Burton Watson. New York: Columbia University Press.

Kaufman-Osborn, Timothy V. 1990. "Whither the Political Science Major at Liberal Arts Colleges?' PS: Political Science \& Politics 23:56-61.

Keightley, David N. 1990. "Where Have All the Heroes Gone: Reflections on Protagonists, Art, and Culture in Early China and Early Greece"' (unpublished ms.).

Kermode, Frank. 1983. The Classic: Literary Images of Permanence and Change. Cambridge, MA: Harvard University Press.

Mencius. 1970. Translated with an Introduction by D. C. Lau. New York: Penguin Books.

Mote, Frederick W. 1971. Intellectual Foundations of China. New York: Alfred A. Knopf.

Nussbaum, Martha C., and Amartya Sen. 1989. "Internal Criticism and Indian Rationalist Traditions." In Relativism: Interpretation and Confrontation. $\mathrm{M}$. Krausz, ed., 299-325. Notre Dame: University of Notre Dame Press.

Ober, Josiah. 1989. Mass and Elite in Athenian Democracy. Princeton University Press.

Outlaw, Lucius. 1993. “African, African American, Africana Philosophy." Philosophical Forum 24 63-92.

Passmore, John. 1967. "Philosophy." In The Encyclopedia of Philosophy, ed. Paul Edwards. Vol. 6, 216-26. New York: Macmillan.

Pocock, J.G.A. 1977. “On Thinking About the Untranslatable: the Western Political Theorist's Approach to the Study of Chinese and Japanese Political Thought." Paper presented to the Annual Meeting of the Conference for the Study of Political Thought, Toronto.

Schwartz, Benjamin I. 1964. In Search of Wealth and Power: Yen Fu and the West. Cambridge, MA: Belknap Press.

Schwartz, Benjamin I. 1985. The World of Thought in Ancient China. Cambridge, MA: Belknap Press.

Searle, John. 1990. "The Storm Over the University." New York Review of Books, December 6, 34-42.

Sivin, Nathan. 1984. "Why the Scientific Revolution Did Not Take Place in China-or Didn't It?"' In Transformation and Tradition in the Sciences: Essays in Honor of I. Bernard Cohen, ed. Everett Mendelsohn. Cambridge: Cambridge University Press.

Tu Wei-Ming. 1985. Confucian Thought: Selfhood as Creative Transformation. Albany, NY: SUNY Press.

Wahlke, John C. 1991. "Liberal Learning and the Political Science Major: A Report to the Profession." PS: Political Science \& Politics, 24:48-60.
Waley, Arthur. 1956. Three Ways of Thought in Ancient China. Garden City, NY: Doubleday, Anchor. [reprint].

White, James Boyd. 1984. When Words Lose Their Meaning. Chicago: University of Chicago Press.

Wolfe, Alan. 1989. Whose Keeper? Social Science and Moral Obligation. Berkeley and Los Angeles: University of California Press.

Wong, David. 1989. "Three Kinds of Incommensurability." In Relativism: Interpretation and Confrontation, ed. M. Krausz.

Wu, Kuang-Ming. 1990. The Butterfly as Companion: Meditations on the First Three Chapters of the Chuang Tzu. Albany, NY: SUNY Press.

Yearley, Lee H. 1990. Mencius and Aquinas: Theories of Virtue and Conceptions of Courage. Albany, NY: SUNY Press.

\section{Appendix: Three Syllabuses}

\section{General Studies 204 \\ Sophomore Humanities Seminar: Brave New Worlds}

Format and Assignments: Sections will meet together on Wednesdays, separately for the other two weekly meetings. There will be seven short papers assigned during the course, as indicated below. In lieu of a final examination, there will be an option of re-writing one of the seven papers at the end of the term.

Class Schedule:

Week 1 (January 23-27: Niccolo Machiavelli, The Prince

Week 2 (January 30-February 3): The Prince; Thomas More, Utopia.

Week 3 (February 6-10): Utopia.

First Paper Due More and/or Machiavelli (4-5 pages): Friday, Feb. 10.

Week 4 (February 13-17): K'ang Yu-wei, The One-World Philosophy of $K$ 'ang Yu-Wei, Parts 1 and 2, plus one of the later chapters of your choice (on racism, sexism, etc.).

Second Paper Due (2 pages): Friday, Feb. 17.

Week 5 (February 20-24: William Shakespeare, The Tempest.

Week 6 (February 27-March 3): John Milton, Paradise Lost, Books 1, 2, 3 (lines 1-143), 4, 5, 9, 10.

Third Paper Due Shakespeare (2 pages): Friday, March 3.

Week 7 (March 6-10): Paradise Lost.

Spring Break

Week 8 (March 20-24): Paradise Lost
Fourth Paper Due (4-5 pages): Friday, March 24

Week 9 (March 27-31): Wang Yangming, Inquiry on the "Great Learning'; Instructions for Practical Living, sections $2-7,9-10,15-16,24,26,28$, $30-34,38,44,52,58,62,76,86,99$, $101,122-123,127,134-136,138-139$, $195-200,202,222,226,228,231,272$, 276, 279, 282, 293.

Week 10 (April 3-7): Wang Yang-ming.

Fifth Paper Due (4-5 pages): Friday, April 7

Week 11 (April 10-14): René Descartes, Discourse on Method; Meditations on First Philosophy, Second Meditation.

Week 12 (April 17-21): Descartes

Week 13 (April 24-28): Jonathan Swift, Gulliver's Travels, Parts 1 and 3 (read through once), Part 4 (read carefully).

Sixth Paper Due Descartes and/or Swift (4-5 pages): Friday, April 28

Week 14 (May 1-5): Li Ju-chen, Flowers in the Mirror, pp. 17-133 in the Lin Tai-yi translation (through the voyage to the city of women).

Seventh Paper Due (2 pages): Monday, May 8

Optional Rewrite due end of exam period

\section{Rationale for the Choice and the Order of Reading}

A standard periodization of European and Chinese cultural history lies behind our choice of readings. For Europe, it is conventional to date the beginning of Western "modernity" from around the beginning of the 16th century. This dating assumes that a set of fundamental changes occurred during the period 1500-1789: the breakdown of the feudal order and the emergence of unified nation-states; increasing encounter with non-European people and extensive colonization; the flourishing of commercial markets; the separation of religious and political authority; the emergence of modern natural science; the separation of individual identity from inherited social position. The European readings in the course provide ways of naming and responding to these transformations.

For Chinese intellectual history, it is conventional to distinguish four periods. The first or ancient era runs from about the 6 th to the $2 \mathrm{~d}$ century B.C. (Spring and Autumn Annals and Warring States periods), and centers around 
the classical Confucian and Taoist texts. The second period (sometimes called "medieval" runs from the Han to the Sung dynasties (up to the 10th century A.D.), and features the entry of Buddhism into the Chinese world. The third (sometimes called "modern") is the period of Sung (e.g., Chu Hsi) and Ming neo-Confucianism (from the 11 th through the 18 th centuries), a series of attempts to consolidate and solidify the Confucian tradition in ways that take account of the challenges of Buddhism and of popular Taoism. Last is the contemporary period, the 19th and 20th centuries, characterized by responses to the challenge of Europe.

We begin with Machiavelli and More since both of them exhibit a dissatisfaction with the present order of society, and an inclination to look backward as a way of imagining a transformed present-NM explicitly, by recommending the study of history, and More (or Hythloday, at least) by calling up the image of a simpler time or out-oftime. Both also suggest ideas of the virtues that are against their age, and present characters (Hythloday and the Prince) who suggest the figure of the modern "individual," the self-made man. In each there is also a tension between two central elements of the Western tradition, Christianity and classical republicanism. Both texts are also complex in raising questions about the relation of the author to the textMore to Hythloday, Machiavelli to his Florentine counselor.

$\mathrm{K}$ 'ang Yu-wei comes in at a much later period, the 19th century Chinese turn toward the West as threat and promise, but we start here because we think it's good to introduce China as soon as possible, and because the issues here are more easily accessible to students without any knowledge of China than would be the case with earlier texts. K'ang Yu-wei's One-World is a prediction of a utopian future that rests on the premise that neo-Confucianism properly understood can be made fully compatible with the essence of European science and democracy. Here we introduce the idea of a tradition resting upon a set of texts (the Analects of Confucius and related commentaries) and the way controversial interpretations of "sacred" texts can serve to imagine social arrangements and ways of life.

The Tempest introduces one European conception of West and nonWest, and continues the utopian theme, along with introducing the genre of romance. Paradise Lost picks up the theme of interpreting and "justifying" a sacred text begun in $\mathrm{K}$ 'ang Yu-wei, thinking about Milton's new version of Genesis and the idea of an epic poetry that celebrates the world as it is.

Wang Yang-ming (1472-1529) reacted against the neo-Confucian orthodoxy based on the works of Chu Hsi (11301200 ), who was the grand synthesizer and codifier of earlier Chinese thought during the turn to the "modern" period. Wang Yang-ming's was a kind of inward turning, away from rationality and inquiry associated with $\mathrm{Chu} \mathrm{Hsi}$, toward insistence on innate knowledge of the good, a connection between the structure of the human soul $(h \sin )$ and the structure of the cosmos, a unity of thought and action-all made compatible with traditional filial piety.

Descartes also turns inward in his self-consciously novel and anti-traditional rules for both intellectual and moral conduct. To be stressed here is the Cartesian dichotomy between spiritual and material things, and his attack on the idea of tradition (including the literary tradition) as such. The Discourse is to be read as a prospective apologia for modern science as a practice or way of life. Genre questions also arise here-what is a work of "'autobiography”, " philosophy”, “science", "fiction", "religion"?

Gulliver's Travels is to be read in part as a critique of the aspirations of the Cartesian Enlightenment, a satire on the new world of science and commerce, one whose ending suggests a picture of modernity as dilemma. We end with Flowers in the Mirror $(\mathrm{Li}$ Ju-chen, 1763-1830), a satiric, though cheerful, novel of voyages to imaginary lands that is in some respects a Chinese Gulliver.

\section{General Studies 204 Piety and Death: China and Greece}

A consideration of some ways in which writers in two cultural contexts gave accounts of the lines separating and connecting the human and the divine, the living and the dead. The focus will be on developing strategies for making sense of challenging and unfamiliar texts, and on figuring out how to get texts from two different traditions to speak to one another. No special background is presupposed, and there are no prerequisites. The course has been designed with sophomores and juniors primarily in mind.

There will be six short papers (total length, approximately 25 pages). The papers will be on the texts discussed in class. Because of its writing-intensive character, the course is not open to freshmen except those who are exempt from English 015.

\section{Schedule of Readings and Papers:}

September 4 and 6: Introduction: Historical background: China in the Spring and Autumn Annals and Warring States periods (722-222 B.C.E.) and the Athenian polis in the 5th and 4th centuries B.C.E. Consideration of selected sample Chinese and Greek texts from the period.

September 9, 11, 13: Sophocles (496406): Antigone

September 16, 18, 20: Plato (429-347): Euthyphro

First paper due, September 23

September 23, 25, 27: Confucius (551479): Analects

Second Paper due, September 30

September 30, October 2, 4: Hsün Tzu (about 310-230)

October 7, 9, 11: Hsün Tzu

October 14: Fall break

Third Paper due, October 16

October 16, 18: Thucydides (about 460400): Peloponnesian War

October 21, 23, 25: Thucydides

Fourth paper due, October 28

October 28, 30, November 1: Aristophanes (about 455-385): Birds

November 4, 6, 8: Euripides (about 485406): Helen

Fifth paper due, November 11

November 11, 13, 15: Chuang Tzu (between 399 and 295)

November 18, 20, 22: Plato, Apology and Crito

November 25: Plato

Sixth paper due, November 27

November 27: Ying Shao, “On Marvels and Spirits"

November 29: Thanksgiving break

December 2, 4, 6: Euripides: Bacchae

December 9: Bacchae

There will be a self-scheduled final examination.

\section{Rationale for the Choice and the Order of the Readings}

We see the books and authors we have chosen not as representatives of standard Greek or Chinese opinions 
about piety and death, but as texts that introduce problems and perplexities about these matters, and are as a result open to a variety of interpretations and re-interpretations. The order of readings is therefore neither chronological nor one-culture or one-genre-at-a-time, but designed to generate as high a level of interpretive comparison among texts as possible, both in class discussions and in student papers.

We will begin with the Antigone because it seems the most accessible and exciting point of entry into thinking and speaking about the obligations of the living to the dead, about possible conflicts between family and citizenship, and about the tensions between understanding the human world in terms of secular interest and understanding it in terms of our exchanges with divinity. The Antigone is also valuable as a text with several distinct voices and considerable uncertainty about how we are to understand them. Plato's Euthyphro continues all of these questions concerning the relationship of the polis to divinity as well as bringing out another that is also implicit in Antigone: What is the relationship of the philosopher or poet to both polis and the gods?

Confucius' Analects allows us to talk about the issues of piety and death in relation to a text that is aphoristic rather than dramatic, and so to confront and articulate a different form of uncertainty in interpretation. The uncertainty and the question of possible irony is especially complex here, since Confucius is famous for his asserted unwillingness to speak about spirits or the dead. Moreover, Confucius insists that he is saying nothing new in his own voice, but instead transmitting and reviving a faded and precious antiquity. His love of the past, however, is not a passive reverence or a turning away from the present but the basis and incentive for proposing what he calls a correction or rectification of language. How can his stance-that of the teacher or scholar-toward "the tradition" be compared with that of the poet or the philosopher in Athens? What new insights and questions can such comparison yield?

In trying to make sense of the Confucian concepts of filial piety (hsiao), goodness (jên), virtue or moral force $(t \hat{e})$, and rites of ceremony (li), among others, we have the chance to introduce the general question of similarities and differences, analogies and disanalogies between The Analects and the texts of Sophocles and Plato studied earlier-an interpretive procedure that can be continued throughout the course. We can also begin to consider some larger comparative questions about the possibility that we are seeing analogous ways of understanding the world and our place in it-analogies, for example, between the Chinese concepts tao (way), li, and fa (law) and the Greek nomos and physis, or between the ways of imagining equality and hierarchy (as well as unity and difference) among human beings that are implicit in the representations of the empire ruled by the son of heaven and the democratic polis ruled by a political elite.

Hsün Tzu is an author who attempts to clarify and extend Confucian insights and the Confucian project of rectifying language in opposition both to other Confucians (e.g., Mencius) and to some outside the school entirely (examples: Chuang Tzu and the Mohists). By placing the Hsün Tzu at this point in the course, we can continue working within the tradition of Confucianism for another several weeks, this time by examining a text that is easier for students to grasp at first reading than the Analects, since it proceeds by connected reflection and systematic argument rather than aphoristically, and since it is explicitly concerned with causality. At the same time, it is more clearly rooted in a context of an intense debate within Chinese culture concerning the meaning of piety and ritual and of the appropriate relationship of the human and the divine, of the transcendent principles of heaven or the cosmos and the humanly conceived rules and forms of social life.

The paper to be written at this point may be a little more substantial than the first two, since students should now be able both to return to the Analects and to reconsider the Greek texts as sources for their own delineations of Chinese-Greek analogy and difference. As in all the papers from here on, we will ask students to focus on some problem about the meaning or structure of a given text while bearing in mind the way in which other texts can clarify or interestingly complicate that problem.

In reading Thucydides over the following two weeks, we can indicate points of possible connectiof between the interest in discerning causes his account of the Peloponnesian war shares with Hsün Tzu, and their shared sense of the possibility of a divine order that somehow lurks within human historythough not in any simple or simply visible way: Thucydides takes his distance from traditional Greek divination practices; Hsün Tzu is unremittingly hostile towards their Chinese counterparts. It might also be suggested that Thucydides' assertion that his own written composition is a "thing for all times," as well as his argument for the crucial importance of the possibility of meaningful speech within and among poleis raises interesting points of comparison with Hsün Tzu's discussion of the redemptive function of rites and music in human life.

The next two readings, the Birds and Helen, are a clear change of pace. These plays serve as a kind of bridge section of the course, separating works that take Greek or Chinese cultural tradition seriously from those which in one way or another appear (though perhaps it is only an appearance) to suggest radical revisions. Aristophanes' comedy and Euripides' play are both fantasies that draw attention to their own status as inventive reconceptions of the intermingling of divinity and humanity. These works of the imagination draw attention to their attempt to open up new ways of thinking and writing about divinity, ways that seem to demythologize traditional accounts of gods and heroes, of heaven and earth, perhaps reducing the sense of distance, and surely reducing the sense of solemnity that seems to accompany traditional Athenian piety. Do they also subvert it?

In the last section of the course we encounter three (or perhaps six, counting authors) extraordinary figures who appear to live in the borderlands between divinity and humanity, each of them singularly attractive and disconcerting: Chuang Tzu, Plato's Socrates, and Euripides' Dionysus. The texts considered here also firmly connect the human awareness of divinity to the human experience of death, sometimes elaborately horrible death.

Chuang Tzu, perhaps in a way analogous to the aporia-inducing Socrates, seems wholeheartedly both to reject and to endorse contemporary conventions, to pass beyond words and yet to live within a storm of word-play, to withdraw from the ordinary world of mortals and yet to interrogate that world with persistent and serious engagement. Do ironies operate in Chuang Tzu's fables, as they may in Socratic speech? What is the status of the sometimes conflicting theories and doctrines that both Chuang Tzu and Socrates assert? Are they better understood as revered sages of Taoism and the Higher Law respectively, or as figures who jokingly initiate us into a way that is not quite either the tao or a nomos?

The Bacchae is the last item on the agenda, not because it in some way sums up lines that will have been followed in the rest of the course, but because it contains so many interpretive 
possibilities (and so many fireworks) that it stands a fair chance of combating any end-of-semester depression that may infiltrate our closing discussion of piety and death.

\section{Philosophy/Political Science 306 Origins of Philosophy: China and Greece}

A consideration of the period between the 6th and the 3rd centuries B.C., when certain individuals in both China and Greece began to regard critically and self-consciously the cultures in which they lived.

Requirements: Students are expected to do the assigned readings before coming to class; informed participation in class discussion will be an element of the final grade. There will be four short papers (total length: $20-25$ pages) as indicated below. These will be interpretive essays on the texts we consider in class. There will be a self-scheduled final examination.

Schedule of Readings and Papers

January 19: Introduction

January 21: Benjamin Schwartz, Introduction and Chapter 1 from The World of Thought in Ancient China (xeroxed handout)
January 26 and 28: Cho-yun Hsu, Ancient China in Transition Frank J. Frost, Greek Society, chs. 1-5

February 2 and 4: Confucius (551-479): Anlects, esp. Chs. 1-9, 12, 13 Thucydides (about 460-400): The Peloponnesian War (pp. 35-49, 72-87, 143-164, 212-245, 400-437, 455-470, 516-537)

February 9 and 11: Confucius and Thucydides

February 16: Confucius and Thucydides

February 17: First Paper Due, 5 P.M.

February 18: Chuang Tzu (between 339 and 295) Heraclitus (fl. 500) and Parmenides (fl. 475), Fragments (xeroxed handout)

February 23 and 25: Chuang Tzu and Pre-Socratics

March 1 and 3: Chuang Tzu and PreSocratics

March 4: Second Paper Due, 5 P.M.

Spring Break

March 15 and 17: Mencius (371-289?) Plato (429-347): Phaedrus

March 22 and 24: Mencius and Phaedrus

March 29 and 31: Mencius and Phaedrus
April 4: Third Paper Due, 5 P.M.

April 5 and 7:Hsün Tzu (fl. 298-238)

Aristotle (384-322): Nicomachean

Ethics

April 12 and 14: Hsün Tzu and Aristotle, Parts of Animals, Book 1 (xeroxed handout)

April 19 and 21: Hsün Tzu and Aristotle

April 26 and 28: Hsün Tzu and Aristotle

Final Paper Due-Last Day for Written Work

\begin{abstract}
About the Authors
Stephen G. Salkever is Mary Katherine Woodworth Professor of Political Science at Bryn Mawr College. He is the author of Finding the Mean: Theory and Practice in Aristotelian Political Philosophy (paperback re-issue, 1994).

Michael Nylan is associate professor of East Asian Studies at Bryn Mawr College. She has written two books on early Chinese political philosophy: The Shifting Center: The Original "Great Plan" and Later Readings (1992) and The Canon of Supreme Mystery by Yang Hsiung (1993).
\end{abstract}

\title{
Space Bridges: The U.S.-Soviet Space Bridge Resource Center
}

\author{
Helene Keyssar, University of California, San Diego
}

The airing in the Soviet Union of the Donahue space bridges transformed the Soviet public's image of itself." Interview with Vladimir Pozner, Moscow, 1989

After Remembering War, when I toured the Soviet Union as a musician, even in the remotest village, people came up and hailed me as a hero.

S. Frederick Starr, President, Oberlin College, jazz clarinetist, Sovietologist and U.S. moderator for Remembering War

\section{The Growth of a Medium}

During the decade 1982-92, groups in the United States joined with various Soviet institutions to develop new forms of communication between citizens of the United States and the former Soviet Union. They did so in an era that began with deep mutual mistrust and ended in bewilderment, an era that began with the president of the United States referring to the Soviet Union as the "evil empire," and ended with the dissolution of the Soviet Union itself.

One result of efforts to exploit and effect changing climates of opinion in both the United States and the Soviet Union has been the emergence of a new cultural form called the "space bridge." Translated from the Russian word, telemost, a space bridge is an inter- active television link between at least two geographically separate and culturally distinct locations.

In contrast to teleconferences, space bridges are public events. Whereas teleconferencing brings together small groups for specialized discussions or lectures on interactive television, space bridges are more like interactive theater, in which the dialogue occurs between sites as well as between key participants, moderators, and unnamed audience members. Space bridges provide a space in which ordinary citizens can appear in public as a public.

I first became interested in space bridges in the summer of 1983 . 